\title{
SAINT AMBROSE OF MILAN AS A DEFENDER OF THE FAITH IN THE GREEK HYMNOGRAPHY
}

Saint Ambrose became known especially because of two things: his contribution in the Arian controversy and his conflict with the emperor Theodosius after the killing of many people in Thessalonica at 390. His theological explanations circulated throughout the Roman empire. Especially one sentence was quoted by the theologians: „Servemus dictinctionem divinitatis et carnis. Unus in utraque loquitur Dei Filius, qui in eodem utraque natura est; et si idem loquitur, non uno semper loquitur modo" 1 . This sentence has been taken to many Latin and Greek Florilegia and was commented on many ways ${ }^{2}$.

His victory over the emperor passed into history and into hymnography. Paulinus of Milan gives a very short relation about this event:

„The emperor declared that David had committed adultery and also homicide. But straightway the reply was given: «You who have followed him as he sinned, follow him as he corrected himself». When the most merciful emperor heard this, he so took it to heart that he did not scorn public penance, and the progress of this correction prepared for him a favourable victory" ${ }^{\prime 3}$.

There is more information on this matter in the Letter to the Emperor Theodosius of Ambrose himself ${ }^{4}$. St Hieronymus does not speak about it either in his work De viris illustribus or in his Chronicle. In the Greek historiography the same event is presented as a triumph of the bishop over the emperor ${ }^{5}$.

${ }^{1}$ Ambrosius, De fide ad Gratianum 99, 9, 77, PL 16, 576B: „Let us keep distinction between the divinity and body. The same Son of God speaks in both, because He remains in both natures. When he speaks, he does not speak in the same way" (own translation).

2 Cfr. G. Bardy, Sur une citation de saint Ambroise dans les controverses christologiques, RHE 40 (1944/1945) 171-176. Even Photius commented this sentence in his Bibliothaeca III 229, PG 103, 977 A.

${ }^{3}$ Paulinus Mediolanensis, Vita Sancti Ambrosii VII 24, PL 14, 37-38, trans. M.S. Kaniecka, Washington 1928, 65-67.

${ }^{4}$ Cfr. Ambrosius, Epistola 51 (ad Theodosium), PL 16, 1209-1213, trans. H. de Romerstin, in: Nicene and Post-Nicene Fathers (= NPNF), vol. 10, Peabody, Massachusetts 1994, vol. 10, 450-451. 
The popularity of St Ambrose in the Oriental Church is to be realized in the Greek historiography ${ }^{6}$ and in the hymnography as well. There is a collection of Greek hymns composed on his honour. Together about 50 small works. In the edition by C. Pasini they are divided into several groups: kontakions, kanons, odes, theotokions, sticheras, kathismas, exaposteilarions) ${ }^{7}$. Each kind of hymns has its specific character. Their aim was to glorify God, to honour Holy Mary and saints (Ambrose, Athenadore) and to proclaim a message. Especially the kontakions were composed for the proclamation of the Christian doctrine and for the refutation of heresies. According to E. Wellesz, ,the kontakion is a poetical homily; the nine Odes of every kanon are modelled on the pattern of the Nine Canticles from the Scriptures and have the character of hymns of praise. Whatever the object of a kanon may be the celebration of a feast of Christ or the Theotokos, or the commemoration of a saint or a martyr - the hymn writer had to allude in each of the nine Odes to its scriptural model"8. J. Grosdidier de Matons agrees with such an opinion ${ }^{9}$. The origin of kontakion seems to be Semitic, probably Syrian. The kontakions were composed especially for the ordinary people; they were sung during the vigils (vigiliae) before solemnities and - sometimes - for private lecture ${ }^{10}$. The hymns in honour of St Ambrose were conserved in the books of hymns called Kontakaria, Menei. It is possible that they come from the monastic milieu (perhaps in Syria) ${ }^{11}$ because there are many allusions to the theological controversies and to the conflict of Ambrose with Theodosius. It may be especially the case of Kontakion IV and VI, which were conserved in Kontakaria in the monastic centre of Athos (Movì

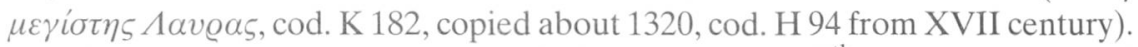

Those hymns are composed probably in the VI-VII ${ }^{\text {th }}$ centuries, some of them may come from the VIII and IX $^{\text {th }}$ centuries. They were inspired by

${ }^{5}$ Cfr. Sozomenus, Historia Ecclesiastica VII 25, PG 67, 1493-1496. Evagrius Scholasticus placed St Ambrose among the saints Fathers like Gregory, Basil, Hilary, Athanasius, Cyrill, without speaking about his conflict with Theodosius (HE II 18, PG 86/2, 2557). Zosimos does not speak about him at all.

${ }^{6}$ Cfr. J. Grzywaczewski, Recepcja św. Ambrożego w Kościele Wschodnim (Saint Ambrose in the Oriental Church), VoxP 18 (1998) t. 34-35, 227-256.

7 Cfr. C. Pasini, Le fonti greche su Sant'Ambrogio di Milano, SAEMO 24/1 (Sussidi), MilanoRoma 1990, 336-431.

${ }^{8}$ Cfr. E. Wellesz, A History of Byzantine Music and Hymnography, Oxford 1949, 198.

${ }^{9}$ Cfr. J. Grosdidier de Matons, Recherches sur Romanos le Mélode et sur les origines de Kontakion, Paris 1961, 176: „Le kontakion est une homélie, ou, à la différence du canon qui est un poème lyrique, le texte est plus important que la musique. Le chant devrait être simple et peu orné"; see also ibidem, pp. 73, 111, 114.

${ }^{10}$ Cfr. Grosdidier de Matons, Recherches sur Romanos le Mélode, p. 122: „Nous avons affaire à un genre qui n'était pas destiné au chant, mais à la récitation et même à la lecture individuelle".

${ }_{11}$ Generally, the compositions like kontakions, kanons, troparia were not accepted in monasteries, especially in Egypt. The monks gave priority to the Psalms, see Wellesz, A History of Byzantine Music, p. 171. 
Romanos Melodus ( $† 540$ ), a deacon of Constantinople, probably with Jewish origin $^{12}$. In the hymns there are many references to the Bible and many elements of oriental poetry. It is difficult to identify the author of every hymn. In several cases the name of the author is indicated: the first one is Joseph - it is probably Joseph of Sicily ( $† 886$ ), a monk who was known as an author of hymns. There are two other names: Theophan and Ignatius. Theophan is a composer of hymns of the monastery in Saba in Palestine ( $†$ 845), Ignatius was a monk in Constantinople in the time of Photius. The third name is George; probably this refers to the bishop of Nikomedia who was known as preacher and composer of hymns ${ }^{13}$. Some kanons in honour of Ambrose are attributed to Andrew of Crete $(\dagger 740)$, several kontakaria - to Talas, a monk of Constantinople. In the literary character of the kanons, one can notice an influence of the hymns of John of Damascus.

In the collection there are some small works (sticheri, kathismata, exaposteilaria). It is difficult to determine their origin ${ }^{14}$. Probably they were sung especially on the feast of St Ambrose.

The majority of the hymns are in a form of prayer addressed to Saint Ambrose; it means that they were composed as hymns of cult; surely such a cult was developed in the Oriental Church in that time. It is said that:

,the wise bishop, because of his merits and his virtues, has been accepted to the choirs of martyrs, prophets, apostles"15.

For this reason he is glorified as a man who was established as a light „to

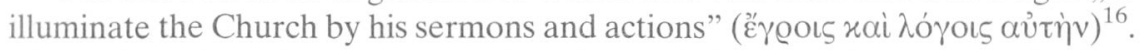
The author of one kontakion testifies his own healing on the tomb of Ambro$\mathrm{se}^{17}$. The theologians point out that Ambrose was honoured as a saint without being monk nor martyr. In the first centuries there was a tradition to honour those who passed on by martyrdom. For this reason, Ambrose may be consi-

${ }^{12}$ Cfr. Grosdidier de Matons, Recherches sur Romanos le Mélode, p. 112.

${ }^{13}$ Cfr. C. Pasini, Le fonti greche su Sant'Ambrogio di Milano, 312-317.

${ }^{14}$ Cfr. ibidem, p. 320: „Pur non potendo offrire indicazioni precise sull'origine e lo sviluppo di ciascuna di queste composizioni minori”.

${ }^{15}$ Kontakion I 45, SAEMO 24/1, 338.

16 Georgii Canones: Oda VII 100, SAEMO 24/1, 398.

17 Cfr. Kontakion VII 5-10, SAEMO 24/1, 350: „The people discovered your holy temple and go there asking for healing from their diseases and for pardon of sins [...]. O wise Ambrose, on your tomb spread out healing; many persons are cured on body and spirit. I did experience it myself and for this reason I praise you". By this strophe two things seem to be certified: the cult of St Ambrose on his tomb in Milan and the fact that this cult was known not only in the West, but also in the eastern part of the Roman Empire. The tomb of Ambrose has been found at 1864 in the ruins of the Basilica Ambrosiana in Milan. According to Paulinus (Vita S. Ambrosii 10, 48, PL 14, 46), the cult started just after his death; J.S. Partyka, Derniers moments, tombeau, reliques et culte de St. Ambroise, VoxP 18 (1998) t. 34-35, 19-35. 
dered a new model of holiness ${ }^{18}$. We will use the Greek text of those hymns edited by Pasini in the English translation of the author of this article.

1. The defence of the faith by teaching. In all hymns Ambrose is glorified as the one who has been established by Christ himself to proclaim the truth. He

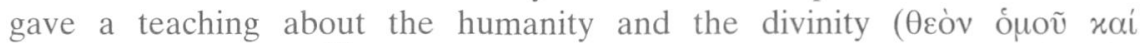

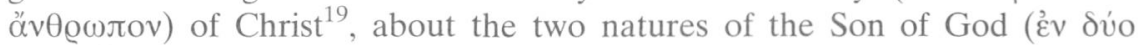



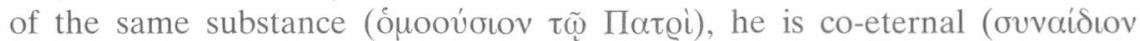

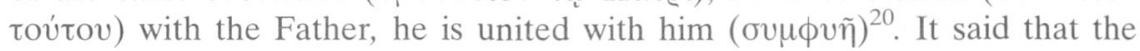
bishop gave his explanations about two natures of Christ and about his common substance with the Father in a „synod of those who bring God” (ovvódw $\theta \varepsilon o \phi o ́ \varrho \omega v)$. Pasini supposes that it may be an allusion to the synod of Rome at 382 or to another synod in Rome ${ }^{21}$. It is to be noticed that the author of those

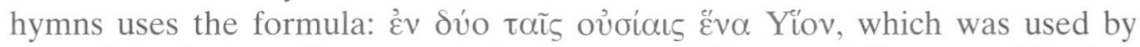
several theologians (for example by Gregory of Nyssa and Gregory of Nazianzus) during the $I V^{\text {th }}$ century and officially has been accepted by the Church in the Council of Chalcedon $(451)^{22}$.

Ambrose was able to give such a teaching not because of his erudition, but because his intellect was ,illuminated by the Holy Spirit" ${ }^{23}$ or because he was ,acting in the power of the Holy Spirit" 24 . He taught the truth which he received from above. Such a teaching, compared to the light, had an effect on the heretics who remained in darkness.

The author of the hymns knew the theological controversies, but he did not want to explore the details. He preferred to express his admiration for Ambrose as ,a man of the Truth”, he wanted to glorify the purity of his doctrine

18 Cfr. Ph. Régérat, Un nouveau modèle de sainteté. Ambroise de Milan, VoxP 18 (1998) t. 34 $35,60-63$.

19 Cfr. Kontakion I 5, SAEMO 24/1, 336.

${ }^{20}$ Cfr. Stichera VI 20, SAEMO 24/1, 408.

${ }^{21}$ Cfr. Pasini, Le fonti greche su Sant'Ambrogio di Milano, p. 409. The participation of Ambrose on the synod of Rome at 382 is attested by Hefele: „Le concile romain auquel les évêques avaient été invites par la lettre synodale, était le cinquième tenu sous le pape Damase. Outre ce pape, il compta parmi ses membres saint Ambroise de Milan [...]. Les actes de ce concile ne nous sont pas parvenus et nous ne savons que peu de choses à son sujet. Il aurait surtout condamné l'hérésie des apollinaristes [...]. Le concile retrancha de sa communion Flavien d'Antioche, Diodore de Tarse et Acace de Bérée" (Histoire des conciles, vol. II/1, Paris 1908, 57-63).

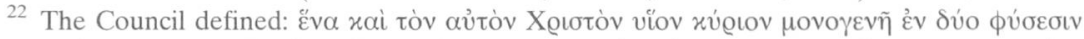

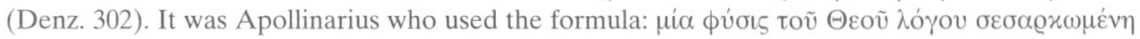
(F. Young, From Nicaea to Chalcedon, London 1983, 182-191).

23 Cfr. Kontakion I 2 and 15; Josephi Canones: Odae I 15 and IX 200, SAEMO 24/1, 336, 354 and 368 .

${ }^{24}$ Cfr. Josephi Canones: Odae IV 65; V 85; VIII 160, SAEMO 24/1, 358, 360 and 366; Stichera VII 35; VIII 5; XIV 1, SAEMO 24/1, 410 and 416. 
and his ability to refute the heretic opinions. Some of the heterodox theologians are indicated by name. In the first place is Arius. For example:

„By your prudent and holy words, you withdraw the Arian pestilence. As a good pastor, o you wise man, you lead your pupils to the pasture of orthodoxy"25.

There is another very similar stanza:

„You saved your herd from any damage which might be caused by the enemies.

O happy man, by your brilliant sermons, you pushed the errors of Arius away"26.

In the same way are named Nestorius and Eunomius ${ }^{27}$. Several hymns end by acclamation: „Expelling the error of heresy”, which was probably repeated by the people.

In all hymns Ambrose is presented in poetic metaphors as a good pastor and teacher who knew how to preach the Divine doctrine. Let us quote several fragments:

„Today wise Ambrose poured out the jug of ambrosia to the faithful and led them to the banquet [...]. Now, Ambrose, pastor of the pastors, father of the fathers, you entered the eternal joy, You share in the eternal life. You have a name of glory and of Divine thought" ${ }^{28}$.

Surely, by ,jug of ambrosia” and by his „name of Divine thought” the author means his teaching. In this context, it is stressed out that wise Ambrose, following

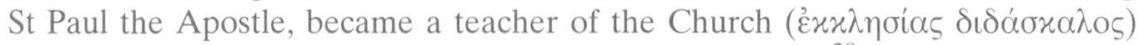
and protected the faithful from the precipice of ignorance ${ }^{29}$. The subject of the knowledge and of the teaching of St Ambrose was especially Holy Scripture:

"The saint Bishop, inspired by God and initiated in a deep knowledge of the Scripture ( $\pi \tilde{\alpha} \sigma \alpha v$ vó $\sigma \omega_{v} \Gamma \varrho \alpha \phi \tilde{\eta} \varsigma$ ), was able to explain to the others, in a correct way, the difficult things" ${ }^{\prime 30}$.

In another hymn there is some more detail about the „difficult things”:

„O Ambrose, you became defender of the orthodoxy, pedestal of the Church, support of the bishops, wise pastor of the sheep. You led the herd to the pasture, you expelled as savage animals the arrogant and flocks of those who had a bad

25 Josephi Canones: Oda I 20, SAEMO 24/1, 354 (

26 Ibidem: Oda IV 60, SAEMO 24/1, 358 ( 24/1, 418; Exaposteilarion II 5, SAEMO 24/1, 424; Christofori Mitileni, Kalendarium metricum. Oda III, SAEMO 24/1, 431.


Kalendarium metricum. Oda III, SAEMO 24/1, 431.

${ }^{28}$ Kontakion II 1-10, SAEMO 24/1, 340.

29 Cfr. Kontakion V 1, SAEMO 24/1, 344.

30 Josephi Canones: Oda III 30, SAEMO 24/1, 356. 


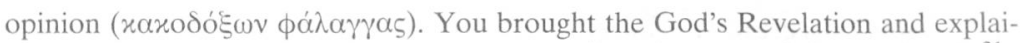

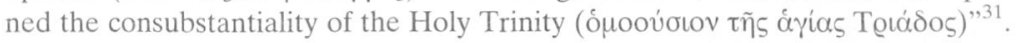

It is clear that the author of this hymn remains in opposition to the Arian doctrine and keeps the Nicene tradition. In the hymns there are many passages in which Ambrose is admired because of his knowledge and teaching and because of his attitude towards those who propagate theological errors.

2. The defence of the faith by action. Another motif in the hymns it is the admiration of the bishop of Milan because of his actions, especially against the emperor Theodosius; one day he was angry with the inhabitants of Thessalonica and ordered to kill many people in the theatre (390). When he came to Milan, he wanted to enter the church and take part, as usual, in the solemn Liturgy. Ambrose did not want to celebrate the Masse in his presence. He sent him a letter in which he stressed his fault and gave him advice to accept penitence like David did ${ }^{32}$, and he left the city, saying that he was not in good health. In the beginning of the collection of hymns we find a reference to this event:

„O most happy Father Ambrose, living totally for God among those who remain abroad. Following wisely the zeal of Elijah Tesbite who did not hesitate to reprimand the king because of his wrong doing, you also reprimanded the king dripping with blood and pushed him away from the holy walls of the temple while you remained imperturbable and righteous and courageous like a lion. You care always on the worship of God"33.

Ambrose is compared to the prophet Elijah who reprimanded king Ahab (1Kings 18,$18 ; 21,17-26)$ who recognized his sin and accepted penitence (21, 27). He is also compared to the prophet Nathan who reprimanded the king David:


king, like Nathan rebuked the king David. You excommunicated him, and having corrected him by repentance, you took him into your flock again" ${ }^{\prime 34}$.

The author does not ignore the attitude of Theodosius towards the Christian religion. He knows that he was a pious king (

31 Exaposteilarion I 1-10, SAEMO 24/1, 422. In the collection Opera minora there are several hymns in honour of the Virgin Mary I which the following terms are used: $\Theta \varepsilon o \chi \alpha \varrho i \sigma \tau \varepsilon$ (Josephi

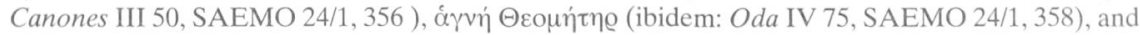
especially @eotóxos (Georgii Canones: Oda I 20; Oda IV 60; Oda VII 140, SAEMO 24/1, 388, 392 and 398) which has been accepted by the Council of Ephesus (431).

32 Cfr. Ambrosius, Epistola 51, 7: „O Emperor, if you say: «I have sinned against the Lord» [...], it will be said to you: «Since you repent, the Lord put away you sin, you will not die» (2Sam. 12, 13)",

${ }^{33}$ Kontakion I 35-40, SAEMO 24/1, 336.

34 Stichera III 20, SAEMO 24/1, 406. 
of this he has sinned. The bishop was obliged to rebuke him and to excommunicate him for a certain time, so that he might be purified by penitence. After the purification, he accepted him to the community of the Church again. It is true that Theodosius, reprimanded by Ambrose, accepted the penitence. Such a decision may be understood as a victory of the bishop, but in fact there was nothing spectacular. It is obvious that Ambrose did not push him away as ,a man of blood". Such a exaggerated relation was developed later, especially in the East as we see it by Greek historians, for example by Theodoret of $\mathrm{Cyr}^{35}$ and by Gregory Monk ${ }^{36}$. The motif of expelling of the emperor as a cruel man is repeated in another hymn:

„O blessed Ambrose, your zeal was like the zeal of Elijah. You expelled the emperor dripping with blood from the holy walls (of the church), you reprimanded him because of the honour of God"37.

\section{There is a vary similar vision by Sozomen:}

„The emperor went to Milan and wanted to enter the church to pray within its walls. When he drew near the gates of the edifice, he was met by Ambrose, the bishop of the city, who took hold of him by his purple robe, and said to him, in presence of the multitude: «Stand back! A man defiled by sin, and with hands imbrued in blood unjustly shed, is not worthy, without repentance, to enter within these sacred precincts, or partake on the holy mysteries». The emperor, struck with admiration at the boldness of the bishop, began to reflect on his own conduct" ${ }^{38}$.

As we see, the author of the hymns follows the amplified vision of the Greek historians. In other hymns Ambrose is compared to John the Baptist:

"O bishop Ambrose, you like John the Baptist pointed out with courage the king's defects [...]. You decorated the bishop's throne, you converted the unbelievers and fortified the faithful" ${ }^{39}$.

Ambrose reprimanded Theodosius like John the Baptist reprimanded king Herod because of his illegal union with the wife of his brother (Matt. 14, 4). Herodias took revenge on John; she asked for his death during the banquet. Ambrose also had an adventure with a woman:

„There was a bad and bold woman, who in her stupidity, dared approach you to beat you, but you made her die by pronouncing a Divine prophecy"40.

${ }^{35}$ Cfr. Theodoretus Cyrensis, HE V 18, PG 82, 1232-1233 vel GCS 44, 307-309, trans.

B. Jackson, NPNF vol. 3, 1994, 143-145.

${ }^{36}$ Cfr. Gregorius Monachus, Chronicon parvum 6, SAEMO 24/1, 208.

37 Theophanis seu Ignatii Canones: Oda VI 140, SAEMO 24/1, 380.

${ }^{38}$ Sozomenus, HE VII 25, PG 67, 1493-1496, trans. Ch. Hartranft, NPNF vol. 2, 1999, 394-395.

${ }^{39}$ Kathisma III 1-10, SAEMO 24/1, 418.

40 Josephi Canones: Oda III 45, SAEMO 24/1, 356. 
Surely, this is an allusion to an event which happened in Sirmium. The Arian crowds supported by empress Justina, invaded the church. At this moment:

\begin{abstract}
„One girl, more imprudent then the rest, after ascending the tribunal, and seizing the garment of the bishop, since she wished to drag him to a group of women, so that he might be beaten by them and driven from the church, heard these words as he himself was want to relate - «Even I am unworthy of so great an Episcopal office, yet it does not become you or your profession to lay hands on any bishop whatsoever. Wherefore, you should fear the judgment of God lest something may happen to you». The event confirmed his words; on the following day he conducted her dead to the grave repaying kindness for insult" ${ }^{\prime 41}$.
\end{abstract}

After this adventure, Ambrose went back to Milan, but Justina organized another attack on him. She wanted to give two churches to the Arians, one in the city and one in the suburb of Milan, but the bishop, with the faithful defended them ${ }^{42}$. The news about it spread out over the empire. In the opinion of the people, Ambrose was greater then John the Baptist, because John was killed, and Ambrose was victorious thanks to his spiritual strength.

In the hymns which we have analyzed, even if they come from different places and are composed by different authors, there are many common points. There is a proof of a cult of Saint Ambrose in the Christian Orient. Their authors ware inspired by the Greek historians who amplified the person of Ambrose or perhaps they were inspired generally by the Greek tradition. In the works of historians like Sozomen, Theodoret of Cyr, Gregory Monk, we do not see a real person, but a hero, a giant of wisdom and faith. One can say that St Ambrose, lost his human nature and became an icon. The composers were not interested in historical details; they wanted to speak about him not for better knowing of his life and his works, but to make the people admire him as a person inspired by God. For this reason it seems to be permissible to say that the presentation of Ambrose, in Greek history and in the hymnography as well, has an encomiastic and thaumastic character (from $\theta \alpha u \mu \alpha \dot{\zeta} \omega$ - to admire). It is some kind of glorification of God, who shows his power and works in the world through elected persons like the bishop of Milan.

41 Paulinus Mediolanensis, Vita S. Ambrosii 3, 11, PL 14, 33A, Kaniecka, p. 49.

42 Cfr. Sozomenus, HE VII 13, PG 67, 1448AB, Hartranft, p. 384: ,Justina, the mother of the emperor, having espoused the Arian heresy, persecuted Ambrose, bishop of Milan, and disquieted the churches by her efforts to introduce alternations in the Nicene doctrines [...] she represented to her son that he (Ambrose) had insulted her. Valentinian believed this calumny and he sent a party of soldiers against the church. On their reaching the temple, they forced their way to the interior, arrested Ambrose, and were about to lead him into exile, when the people assembled in crowds at the church, and evinced a resolution to die rather than to submit to the banishment of their priest". 


\title{
ŚW. AMBROŻY Z MEDIOLANU JAKO OBROŃCA WIARY W GRECKIEJ HYMNOGRAFII
}

\author{
(Streszczenie)
}

Artykuł został opracowany w oparciu o zbiór hymnów zwanych: kontakiony, theotokiony, kontakaria, kanony, ody, stichery, kathismy, exposteilariony (wydał je C. Passini: Le fonti greche su Sant'Ambrogio di Milano, Milano - Roma 1990, 336431). Są to utwory pochodzące z różnych środowisk i okresów historycznych. Znane są nazwiska tylko niektórych autorów, jak np. Roman Pieśniarz, Teofan, czy Ignacy; część z nich przypisuje się Talasowi z Konstantynopola i Andrzejowi z Krety. Niektóre wykazują duże walory literackie i muzyczne; zachowały się też nieliczne zapisy melodii, nie są to jednak nuty w obecnym tego słowa znaczeniu. Zdaniem badaczy, takich jak Grosdidier de Matons, niektóre hymny były śpiewane w kościele w czasie wigilii przed większymi uroczystościami, a inne były przeznaczone do użytku prywatnego. Przypuszcza się, że mogły być używane jako lektura duchowa. E. Wellesz określa kontakion jako poetycka homilię. Te wspaniałe utwory nie były dotąd znane polskim czytelnikom.

Celem niniejszego artykułu nie jest analiza literacka ani muzyczna hymnów, lecz przybliżenie ich treści. Hymny, skomponowane i wykonywane w języku greckim na Wschodzie opiewają św. Ambrożego Biskupa Mediolanu jako nauczyciela prawdziwej wiary, jako pogromcę herezji, jako wzór cnót chrześcijańskich, a szczególnie jako obrońcę Kościoła przed bezbożnym cesarzem Teodozjuszem (wyolbrzymiony został zwłaszcza incydent w Tessalonikach - 390 r.). Autorzy hymnów wykazują dość dobrą znajomość zagadnień teologicznych, szczególnie dyskutowanych w IV wieku. Idąc za takimi historykami, jak Teodoret z Cyru i Sozomen, kreślą barwny obraz odważnego biskupa, który wobec świty cesarskiej zabrania Teodozjuszowi wejść do kościoła, wykazuje mu zło jego postępku i zmusza do pokuty. Tego rodzaju gloryfikacja łacińskiego biskupa na greckim Wschodzie jest wprost zdumiewająca. Ambroży w wizji hymnografów traci cechy rzeczywiste, a nabiera cech taumastycznych i jeśli można tak powiedzieć - enkomiastycznych, podobnie jak bizantyjska ikona. Staje się on symbolem mocy duchowej, która pokonuje potęgi tego świata. 